Przegląd Badań Edukacyjnych Educational Studies Review

ISSN 1895-4308

nr $31(2 / 2020)$, s. 23-42

ORYGINALNE ARTYKUtY BADAWCZE

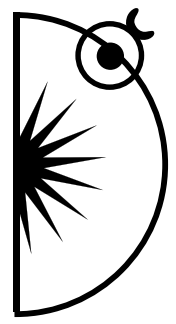

Maria Deptuła

ORCID: 0000-0003-3888-7623

Kazimierz Wielki University in Bydgoszcz, Poland; e-mail: mdeptula@ukw.edu.pl

Anna Borucka

ORCID: 0000-0003-4872-5986

National Bureau for Drug Prevention in Warsaw, Poland; e-mail: anna.borucka@kbpn.gov.pl

\title{
School Risk Factors in Developing a Sense of Competence by Polish Pupils: Their Fourth and Fifth Year of Learning at Primary School - Longitudinal Studies*
}

http://dx.doi.org/10.12775/PBE.2020.017

\begin{abstract}
The article presents the results of a qualitative and quantitative analysis of school pupil responses to open-ended questions concerning their desired changes during lessons. The studies were carried out in Poland, in primary schools, at the beginning and end of the fourth year of learning and at the end of the fifth year of learning (the mean age of respondents participating in the measurement was 9 years and 7 months). They included a diagnosis of the conditions and effects of psychosocial development. Every respondent was characterised
\end{abstract}

* The study was carried out within the "Niebieskoocy" w naszej szkole - przezwyciężanie stereotypów droga do tworzenia uczniom lepszych warunków rozwoju [The "Blue Eyed" in Our School - Overcoming Stereotypes as the Pathway to Creating Better Conditions for Pupil Development in the School Class] under the National Health Programme for 2016-2020, Agreement No. UKW No. 6/53/3.4.3/17/DEA. The research programme received a positive opinion from the Research Ethics Committee at the Institute of Pedagogy of the Kazimierz Wielki University in Poland. 
based on a diagnosis on a scale called the Indeks Ryzyka [Risk Index] built on the results from nine variables describing the conditions of psychosocial development in a school class and such effects of psychosocial development as: a sense of helplessness and stereotype threat of low abilities in Polish language and maths lessons, as well as the explanatory style assumed by pupils to explain their own successes and failures in learning. A risk category for the improper execution of a developmental task was identified for each variable - instead of the development of a sense of competence there was a dominance of feelings of inferiority and the Risk Index (RI) scale was construed on this basis.

An analysis of the reactions of pupils to the possibility of suggesting changes in the hitherto work of teachers during lessons indicates that only towards the end of the fifth year of learning did the position on the RI scale statistically significantly differentiate the frequency of acceptance of the status quo reported by the respondents, the need for change, or not taking up the chance to express one's views on the topic. The qualitative analysis of the content of the respondent statements led to the identification of two main categories: (1) Needs relating to the everyday relationships between teachers and pupils, and (2) Needs associated with the teaching process. In the first pupil statement category, they usually expressed the desire for teachers to stop raising their voice or shouting during lessons, in the second, they concerned ensuring peace and quiet during lessons and slowing down the pace of work. A list of the topics mentioned by the pupils forms a list of the most pressing changes - from the pupils' perspective-in the work of teachers during lessons.

Key words: pupils' needs; a sense of competence; school risk factors; risk index; middle school age.

\section{Introduction}

The studies, a fragment of which is here presented, are underpinned by the conviction that the fundamental task of teachers in school is creating the conditions for development and only secondarily to execute the core curriculum. According to humanistic psychology, this means helping to acquire such experiences, knowledge, and level of personal development that will enable them to deal more constructively with the "real world" (Rogers, 1961).

The aim of this article is to present the needs reported by pupils that are directly related to the manner in which teachers work during lessons. It also intends to reveal how these expectations change over two years of school attendance in privileged groups of children in terms of their chances of executing a developmental task that, according to Erik H. Erikson's concept of psychosocial development (1950; Witkowski, 1989; 2015), occurs between 7 and 12 years of age. The theoretical underpinnings for the diagnosis leading to the identification of the risk factors and groups is social psychology of develop- 
ment in the approach of Anna I. Brzezińska and her students (Brzezińska, 2000; 2005a; 2005b; Appelt, 2005; Smykowski, 2012; Brzezińska et al., 2016) and Erikson's concept of psychosocial development. In line with them, the task for this period of life is developing a sense of competence (productivity). This is enabled by an introduction into work culture, dealing with "something serious, similar to what adults do" (Brzezińska et al., 2008, p. 209), bringing actions to completion, and experiencing recognition for the outcomes of their own work. According to Brzezińska (2005a), the successful completion of the task depends on non-specific conditions that are important throughout the entire life of a person and specific conditions which are key to the fulfilment of a given developmental task. The non-specific conditions include the possibility of satisfying the basic psychological needs of: security, good emotional contact and bonding, autonomy, as well as causation and control over what is happening around them. The specific conditions cover aligning the challenges posed in relation to children to their abilities, and supporting them without limiting their independence.

The diagnostic procedure based on these assumptions that was developed by Maria Deptuła (Deptuła et al., 2018) and supplemented by Szymon Borsich (Deptuła et al., 2019) covers the conditions of psychosocial development created for pupils in a school class and the effects of such development.

The conditions of psychosocial development of the studied pupils relate to the relationship with peers from their school class and their teachers. Two scales developed by Deptuła were used to investigate the possibilities of satisfying the need for security and broadly understood acceptance in these relationships. The declarations of the pupils concerning the intensity of the stress felt in relation to school and learning and their emotional approach to school were used to make inferences on the conditions of development created in a school class. The assumption was taken that the less secure a pupil feels in their relationship with teachers and peers and the weaker their sense of acceptance, the risk of failure in developing a sense of competence is higher (Kulesza, 2007; Ladd at al., 2008). This risk also increases the stronger the stress relating to school and learning is and the more negative is the pupil's emotional approach to school (Mazur, 2015). The conditions of development thus understood are a "subjective representation of the objective environmental determinants", "a reflection of the characteristics of the school environment experienced by pupils" (Kulesza, 2007, p. 262).

The assumption underpinning the research was that the development of a sense of competence is threatened by the following effects of development: a sense of helplessness, stereotype threat, low abilities in Polish language and maths lessons, and the tendency towards a pessimistic explanatory style assumed by pupils in relation to their own successes and failures in learning. 
A sense of helplessness or stereotype threat of having low abilities makes an individual less involved in the tasks put to them because they do not believe that they will succeed (Seligman et al., 1995; Steele \& Aronson, 1995; Borsich \& Deptuła, 2018; Deptuła, 2019). However, a pessimistic explanatory style increases the risk of attributing failures to fixed factors affecting many areas of activity, and successes to momentary factors with narrow reach. Consequently, the motivation to undertake tasks and perseverance in the face of difficulties dwindles (Seligman, 1995), and this leads to the achievement of lower results.

\section{Method}

The Indeks Ryzyka [Risk Index] (RI) scale was created on the basis of data obtained from measuring nine variables that have been described in Tables 1 and 2 .

Table 1. Measurement of variables constituting the basis for the construction of the Risk Index scale - conditions of psychosocial development in a school class

\begin{tabular}{|l|l|}
\hline \multicolumn{1}{|c|}{ Definition of Variable } & \multicolumn{1}{|c|}{ Measurement Method } \\
\hline $\begin{array}{l}\text { The conditions of psychosocial } \\
\text { development in relationships } \\
\text { with peers and teachers - a frag- } \\
\text { ment of the context for develop- } \\
\text { ment created by the mutual } \\
\text { interactions between the child and } \\
\text { these people. }\end{array}$ & $\begin{array}{l}\text { Scale for measuring the conditions for development in relationships with } \\
\text { peers - 21 items. Examples of questions: What do you think, how many } \\
\text { people from your class would stop doing something that you don't like if } \\
\text { you told them that you don't like that certain thing? 5 response options } \\
\text { ranging from: nobody (0 points) to almost everyone (4). } \\
\text { The scale measuring the conditions for development in relationships } \\
\text { with teachers - 29 items. Examples of questions: What do you think, } \\
\text { for how many teachers is it important how you are feeling and what is } \\
\text { happening to you during lesson? } \\
\text { The response options ranged from: for no teachers at all (0 points) for } \\
\text { all of them (4)*. } \\
\text { There is one open-ended question concerning the desired changes at } \\
\text { the end of each questionnaire. }\end{array}$ \\
\hline $\begin{array}{l}\text { Stress felt in relation to school } \\
\text { and learning - an effect of an im- } \\
\text { balance between the requirements } \\
\text { of the milieu and the resources } \\
\text { held by the individual (Mazur, } \\
2015, \text { p. 72). }\end{array}$ & $\begin{array}{l}\text { One question from the HBSC project: To what extent do you feel stress } \\
\text { related to school and learning? } \\
\text { The four response options ranged from: not at all (3) very strongly (0)** } \\
\text { (Mazur, 2015, p. 73). }\end{array}$ \\
\hline $\begin{array}{l}\text { Approach to school - emo- } \\
\text { tional attitude resulting from the } \\
\text { subjective perception of the school } \\
\text { environment by the pupil (Mazur, } \\
2015, \text { s. 66). }\end{array}$ & $\begin{array}{l}\text { One question from the HBSC project: What do you think about your } \\
\text { school at present? } \\
\text { The four response options ranged from: I don't like it at all (0) I like it } \\
\text { a lot(3)(Mazur, 2015, p. 66). }\end{array}$ \\
\hline
\end{tabular}

\section{Source: Authors' study.}

* The response categories from amongst which the respondents always could choose only one, are construed so that the requirements set before the teachers in relation to the children were higher than the requirements posed to children in their mutual relations (see the response options). The higher the result, the better the conditions for development.

** The responses were modified in relation to the original, where the last two options were: "quite a lot", "a great deal". 
In the concept taken for the diagnosis, the assumption is that the mentioned effects of psychosocial development are not a direct and exclusive effect of the conditions of development. This is because they are determined by various factors, also by the earlier, more differentiated experiences of the studied pupils. However, correlation analyses confirm their statistically significant relationships (Deptuła et al., 2019).

Table 2. Measurement of variables underpinning the Risk Index scale structure effects of psychosocial development

\begin{tabular}{|c|c|}
\hline Definition of Variable & Measurement Method \\
\hline $\begin{array}{l}\text { A sense of helplessness at Polish } \\
\text { language and maths lessons - } \\
\text { "incapacity to fulfil own needs } \\
\text { through own behaviour" in the } \\
\text { objective aspect or the person's } \\
\text { perception of there being no rela- } \\
\text { tionship between their behaviour } \\
\text { and its expected consequences } \\
\text { (Ciżkowicz, 2009, p. 12). }\end{array}$ & $\begin{array}{l}\text { The scale is comprised of } 20 \text { statements. Three of them }(12,15 \text { and } \\
\text { 18) were reformulated following pilot studies to adjust them to the } \\
\text { study children aged } 9-10 \text { years }{ }^{* 3} \text {. } \\
\text { An example of a statement: I'm afraid of being asked to answer } \\
\text { a question in class. } \\
\text { The response options ranged from: never (1 point) to always } \\
\text { (5 points). } \\
\text { The higher the result, the higher the sense of helplessness, which } \\
\text { means smaller chances of being successful at school and of the devel- } \\
\text { opment of a sense of competence by the pupil. }\end{array}$ \\
\hline $\begin{array}{l}\text { A sense of stereotype threat - } \\
\text { a predicament evoked by the fear } \\
\text { of the negative stereotype about } \\
\text { one's social group being confirmed } \\
\text { as a characteristic of the individual } \\
\text { (Steele \& Aronson, 1995). The } \\
\text { Author of the scale, drawing on the } \\
\text { multiple stereotype threat concept } \\
\text { (Shapiro \& Neuberg, 2007), defined } \\
\text { this variable as a sense of threat } \\
\text { due to the possibility of a negative } \\
\text { stereotype threat about their learn- } \\
\text { ing abilities being confirmed as } \\
\text { their self-characteristic or charac- } \\
\text { teristic of the group to which they } \\
\text { belong. The source of this threat } \\
\text { may be the individuals themselves, } \\
\text { the members of the group to which } \\
\text { they belong, or a different group } \\
\text { (Borsich \& Deptuła, 2018). }\end{array}$ & $\begin{array}{l}\text { The scale is comprised of } 18 \text { statements about Polish language or } \\
\text { maths lessons, e.g., I'm anxious and stressed and I forget what } \\
\text { I already know during maths lessons. That's when I'm worried that if } \\
\text { I say something or do the sums wrong: } \\
\text { - The pupils who are considered able will call us names because } \\
\text { we're not doing well } \\
\text { - What I think about myself: "that I don't have the abilities for this", } \\
\text { will be confirmed } \\
\text { - I will let down the pupils who hope that I will show to everyone } \\
\text { what we can do } \\
\text { - I'm going to completely lose faith in the fact that we can learn this. } \\
\text { The response options ranged from: never (0 point) to always } \\
\text { (4 points). } \\
\text { The higher the result, the higher the intensity of a sense of low ability } \\
\text { stereotype threat, which makes it more difficult for the pupils to } \\
\text { execute the tasks to the best of their abilities. }\end{array}$ \\
\hline $\begin{array}{l}\text { The explanatory style of their own } \\
\text { successes and failures in learning: } \\
\text { "the way in which we usually } \\
\text { explain the causes of events", has } \\
\text { three dimensions: } \\
\text { - Personalisation - the cause is } \\
\text { related to the subject or is inde- } \\
\text { pendent of them, }\end{array}$ & $\begin{array}{l}\text { The scale developed by Borsich comprises } 12 \text { items: } 6 \text { concerning } \\
\text { successes and } 6 \text { relating to failures in learning, with } 3 \text { statements for } \\
\text { each of the two dimensions: permanence and pervasiveness; } \\
\text { The responses of the respondents assume a dichotomic form } \\
\text { (1 - constructive explanation, } 0 \text { - unconstructive explanation). Exam- } \\
\text { ples of items in the scale: } \\
\text { You got a much higher mark than usual in the test. I'd think that: } \\
\text { a) I'm able } \\
\text { b) I learnt it this time round. }\end{array}$ \\
\hline
\end{tabular}


Table 2. Measurement of variables underpinning the Risk Index scale structure effects of psychosocial development

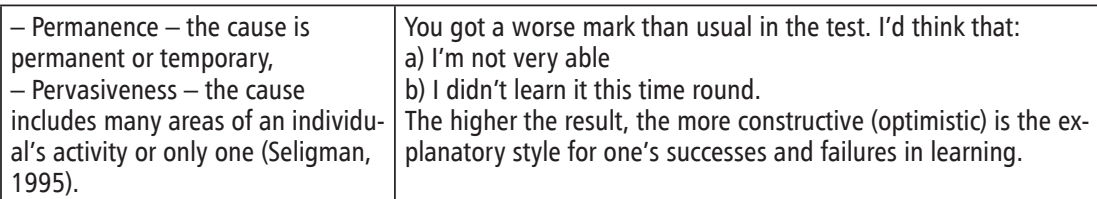

Source: Authors' study.

* Statement 12: I'm sad and resentful - was changed to: discontented. The pupils experienced difficulties in considering two emotional states at the same time in their responses and they did not understand the word resentful. The change eliminated the first difficulty, but the second remained. Therefore, the name of the feeling was explained during the study, referring to the possible circumstances when it could arise. Statement 15 was also changed: I feel just like before a visit to the dentist into I'm annoyed; 18: I'm daydreaming to I'm thinking about things other than this lesson. See Ciżkowicz $(2009$, p. 231) for the original statements.

Table 3 presents data on the reliability of the scale in each of the three measurements ${ }^{1}$.

Table 3. Reliability of the scales measuring the conditions of development and psychosocial effects

\begin{tabular}{|c|c|c|c|c|c|c|c|c|c|}
\hline & \multicolumn{3}{|c|}{ MEASUREMENT 1 } & \multicolumn{3}{c|}{ MEASUREMENT 2 } & \multicolumn{3}{c|}{ MEASUREMENT 3 } \\
\hline & N & Alpha & M.corr. & N & Alpha & M.corr. & N & Alpha & M.corr. \\
\hline RP & 304 & 0.898 & 0.3 & 299 & 0.921 & 0.37 & 281 & 0.935 & 0.42 \\
\hline RT & 304 & 0.93 & 0.33 & 298 & 0.932 & 0.34 & 281 & 0.933 & 0.34 \\
\hline HP & 304 & 0.904 & 0.32 & 299 & 0.934 & 0.42 & 279 & 0.925 & 0.39 \\
\hline HM & 304 & 0.888 & 0.29 & 299 & 0.906 & 0.33 & 279 & 0.901 & 0.33 \\
\hline ST P & 302 & 0.951 & 0.53 & 298 & 0.966 & 0.62 & 274 & 0.963 & 0.61 \\
\hline ST M & 302 & 0.931 & 0.43 & 298 & 0.946 & 0.51 & 274 & 0.942 & 0.49 \\
\hline STYLE & 302 & 0.731 & 0.18 & 298 & 0.783 & 0.24 & 263 & 0.785 & 0.24 \\
\hline
\end{tabular}

Key: M. Corr. - mean correlation between items on the scale; RP - conditions for development in relationships with peers; RT - conditions for development in relationships with teachers, HP - helplessness at Polish language classes; HM - helplessness at maths lessons; ST P - stereotype threat at Polish language lessons; ST M - stereotype threat at maths lessons.

Source: Authors' study.

\section{Description of the Indeks Ryzyka [Risk Index] Scale}

Based on the solutions presented in literature on the subject (Newcomb \& Felix-Ortiz, 1992; Deković, 1999; Ostaszewski \& Zimmermann, 2006; Stoddard et

\footnotetext{
${ }^{1}$ Data on theoretical accuracy is available in the Authors' article.
} 
al., 2013; Ostaszewski, 2014; Forster et al., 2019, Asworth \& Humprey, 2020), the procedure of construing an aggregate risk index was used to assess the level of risk. Ranges were designated in each of the measurements for each scale, within which the results acknowledged as a risk factor of disruptions occurring in the execution of a developmental task by the child. Separate solutions were adopted for these two types of scales due to the fact that 3 out of 7 variables were measured using scales construed so that the higher the result, the better the conditions or effects of psychosocial development, and the remaining were construed in the opposite way. In the case of the conditions of psychosocial development in relationships with peers and teachers and one of the effects of development, namely, the explanatory style for own successes and failures in learning, a result in the lower quartile, that is, ranging from 0 to around $25 \%$ of the lowest results in the studied sample, was assumed to be a risk factor. Results in the upper quartile were accepted as a risk factor when it comes to a sense of helplessness and stereotype threat at Polish language lessons and maths lessons.

For the stress felt in connection with school and learning variable, responses demonstrating that it was felt quite strongly and very strongly were attributed to the risk factor category, while in the scope of the approach to school, responses of: I don't really like it and I don't like it at all were classified as being in the risk factor category.

The measurement of 9 variables allows a result to be obtained for each respondent on a scale called the Indeks Ryzyka [Risk Index] (RI) scale. If a single result of a given person did not fall within the risk factor category, they have 0 points on the RI scale. There is a maximum of 9 points on this scale. In qualitative analyses, only the responses of those respondents for whom results concerning the nine variables were obtained in a given measurement were taken into account.

When identifying the groups on the RI scale, the starting point that was adopted were the conclusions stemming from research relating to the concept of resilience indicating that the action of one or two risk factors usually has a negligible negative impact on psychosocial development and the health of a child; whereas the coexistence of three or more factors may cause maladaptation or disease (Kumpfer, 1999; Masten \& Powell, 2003; Smokowski et al., 2004; Greenberg, 2006). This underpinned the allocation of respondents to one of the groups specified in Table 4. 
Table 4. Criteria and categories on the Risk Index scale

\begin{tabular}{|c|c|}
\hline $\begin{array}{c}\text { Category allocation criterion - result on IR } \\
\text { scale }\end{array}$ & $\begin{array}{c}\text { Risk category for the improper execution of a developmental } \\
\text { task - instead of developing a sense of competence }- \text { the } \\
\text { predominance of feelings of inferiority }\end{array}$ \\
\hline 0 & (1)pupils not threatened \\
\hline $1-2$ & (1) pupils with an average risk level \\
\hline $3-4$ & (2) pupils with an elevated risk level \\
\hline $5-9$ & (3)pupils with a high risk level \\
\hline
\end{tabular}

Source: Authors' study.

\section{Method of qualitative analysis of the written responses of children}

The process of analysis of the content of respondents' answers to the following question: If there is anything that you would like to change in lessons, please write it here, covered several stages. The first consisted of creating a coded key. The exploratory classification model was used for this purpose (Krejtz \& Krejtz, 2005). Two main categories were determined on its basis: (1) Pupils' needs associated with everyday relationships with teachers; (2) Pupils' needs relating to learning. Statements concerning organisational changes at school that are independent of teachers such as the duration of the school year and holidays, and the length of breaks and lessons, were omitted. Stage two involved identifying subcategories grouping the responses of pupils into consistent thematic threads in each of the main categories. Stage three was executed by two judges/researchers independent of each other, and consisted of assigning specific thematic threads appearing in the pupils' statements to relevant categories and subcategories. Discussions on the discrepancies were undertaken in very few cases to reach a consensus.

\section{Respondents}

The respondents were pupils in their fourth year of study from 17 classes that were randomly selected from all the generally accessible classes in the 2017/2018 school year in state primary schools ${ }^{2}$ in Bydgoszcz, Poland. The participation of the child in the study required the written consent of the parent

\footnotetext{
2 Primary school in Poland usually starts at 6/7 years old and ends at the age of 14/15.
} 
or legal guardian to be obtained ${ }^{3}$. The first measurement was carried out at the start of the fourth year of primary school learning ${ }^{4}$. The second was taken towards the end of the fourth year of learning, and the third - towards the end of the fifth year of learning ${ }^{5}$. The level of risk was determined for each respondent separately in each measurement. Results for each of the 9 variables over the three measurements were obtained from 242 respondents.

\section{Results}

In this part, the results of the qualitative analysis of respondent responses on the desired changes during lessons will be presented in turn, followed by the results of the quantitative analysis.

\section{Characteristics of pupils' needs related to everyday relationships with teachers}

An analysis of the content of pupils' statements within category 1 Needs of pupils related to everyday relationships with teachers led to the identification of such subcategories as: the need for security, the need for emotional contact, and the need to be someone important to the teacher. The behaviours of the teachers whom the pupil statements concerned were defined in each of them. A list of subcategories and teacher behaviours along with examples of the pupil statements are presented in Table 5.

${ }^{3}$ A mobile diagnostic lab was used in the studies comprising tablet computers and a router. The pupils completed an online Google Forms survey during lessons, in the presence of a member of the research team. Anonymity was ensured for the respondents and the researchers were given the possibility of comparing the respondents' responses over three subsequent measurements by providing the respondents with the same 7-digit login code randomly drawn by their parents at a meeting presenting the research project. The form tutor passed on a letter that was prepared by the researchers, through the relevant pupil, to parents who were absent from the meeting and the code was drawn by the given pupil before the start of the first survey that was to be completed by the pupils. The individual pupil codes were sealed by them in envelopes and safely stored by the form tutor.

${ }^{4}$ The age in the fourth year of primary school is $9 / 10$ years old.

${ }^{5}$ The age in the fifth year of primary school is $10 / 11$ years old. 
Table 5. Identified subcategories within the main category no. 1 - Needs of pupils associated with everyday relationships with teachers -110 statements

\begin{tabular}{|c|c|}
\hline \multicolumn{2}{|c|}{ The need for security - content of the wishes and examples of pupil statements [53] ${ }^{*}$} \\
\hline Avoiding shouting [37] & $\begin{array}{l}\text { I want the teachers not to shout (1P) Some female teachers shout if we do } \\
\text { something wrong (1P); I'd like to change the fact that when teachers are } \\
\text { angry, they start shouting terribly, which hurts my ears (2P); For the teachers } \\
\text { not to raise their voice at pupils for no reason! (3P). }\end{array}$ \\
\hline Fair treatment [7] & $\begin{array}{l}\text { I'd like teachers to call on all the pupils [to answer a question] and not just } \\
\text { some of them (1P); For my Polish [female] teacher to not just check my exercise } \\
\text { book (2P); For the teachers to be fair in relation to the children and not give } \\
\text { reprimands for no reason (3P); For teachers to treat everyone equally (3P); The } \\
\text { [female] teacher has got it in for me and I don't know what to do with this and } \\
\text { she shouts at me and insults me (3P). }\end{array}$ \\
\hline Protection of reputation [ 3] & $\begin{array}{l}\text { I'd like two teachers from (...) to not say bad things about pupils in front } \\
\text { of the whole class (2P); I'd like teachers not to read the marks out loud (for } \\
\text { the whole class to hear)! (2P); For the teachers not to speak out loud during } \\
\text { lessons about bad marks, etc., because then the whole class makes fun of that } \\
\text { person (3P). }\end{array}$ \\
\hline Avoiding instilling & $\begin{array}{l}\text { For them not to scare us that if we don't learn something then we won't be able } \\
\text { to manage (1P); It's the worst in PE because the [male] teacher shouts at us and } \\
\text { sometimes tries to hit us with the ball but he didn't do it because he's afraid of } \\
\text { the consequences (2P); For us not to be forced to go up to the board (3P). }\end{array}$ \\
\hline Not humiliating the pupil [2] & $\begin{array}{l}\text { I don't I } \\
\text { them (th }\end{array}$ \\
\hline Keeping promises [1] & For them to keep promises (2P). \\
\hline \multicolumn{2}{|c|}{ The need for emotional contact - content of wishes and examples of pupil statements [39] } \\
\hline $\begin{array}{l}\text { Showing kindness, } \\
\text { fondness [27] }\end{array}$ & $\begin{array}{l}\text { (...) and for teachers to be at least a little nicer to everyone (1P); I'd like the } \\
\text { teachers to be nicer to us, just like we are to them (2P); The [female] teacher } \\
(\ldots) \text { is only nasty towards me and I want to change this (3P). }\end{array}$ \\
\hline Forbearance [4] & $\begin{array}{l}\text { For teachers not to get annoyed when I don't understand something (2P); For } \\
\text { teachers to be less strict (1P); For most teachers to be understanding, just like } \\
\text { you are (...) (1P). }\end{array}$ \\
\hline Showi & $\begin{array}{l}\text { I'd like teachers to know what's going on with other pupils at school (2P); } \\
\text { They could also ask from time to time if everything is alright and if we have } \\
\text { any problems (2P); For more teachers to take an interest in me (2P). }\end{array}$ \\
\hline $\begin{array}{l}\text { Listening to what t } \\
\text { has to say [4] }\end{array}$ & $\begin{array}{l}\text { The teacher hearing the child out to the end (2P); For them not to interrupt me } \\
\text { when I'm talking (2P); For teachers to hear us out (3P). }\end{array}$ \\
\hline Showing acceptance [1] & (...) for teachers to like me (1P). \\
\hline \multicolumn{2}{|c|}{$\begin{array}{l}\text { The need to be someone important to the teacher - content of wishes and examples of pupil } \\
\text { statements [18] }\end{array}$} \\
\hline Giving st & $\begin{array}{l}\text { I'd like the teachers to help us more (1P); For all the teachers to encourage } \\
\text { other pupils to work and to learn (2P); For the [male] teacher to come up and } \\
\text { give advice (3P). }\end{array}$ \\
\hline $\begin{array}{l}\text { Showing appreciation of } \\
\text { the pupil [7] }\end{array}$ & $\begin{array}{l}\text { For pupils to only get top marks (1P); For them to appreciate me, just the way } \\
\text { I am (2P); To be the best pupil in the class (3P). }\end{array}$ \\
\hline
\end{tabular}

Source: Authors' research.

* The number of respective statements across three measurements has been provided below the names of categories and subcategories. The measurement from which each statement comes has been provided in brackets. 
It was assumed that the common trait of the behaviours mentioned by the pupils: teachers raising their voice so much that they start shouting, unfair treatment, making public the failures of pupils, insults, failing to keep promises, is creating unpleasant tensions among pupils that may lead to a sense of threat. Unfair treatment limits the chance of anticipating events because rules are not the same for everyone. A similar effect can be triggered by failing to keep promises. The public comments made by teachers in front of the whole class about the failures of a given pupil and insulting them carry a risk for such a fundamental value as good reputation and the need for self-respect. Such an understanding of the need for security is close to the definition formulated by Abraham Maslow (1970), highlighting the predictability of the world, justice, a sense of support and protection, and not experiencing harm.

The behaviours attributed to the need for emotional contact subcategory are characteristic of an attitude facilitating to growth and development (Rogers, 1961). This signifies an unconditional acceptance of the pupil as a person, showing interest in them and their matters, and active and reflective listening to what they have to say. Associated with this are benevolence, understood as a positive attitude towards another person, and forbearance, namely, the propensity to show understanding and forgive faults or improper behaviour (Żmigrodzki, 2010). Experiencing such treatment leads to a feeling of good emotional contact (Obuchowski, 1966) and a positive emotional self-regard.

The last subcategory called the need to be someone important to the teach$e r$, to which such teacher behaviours as giving support and appreciation were allocated, indicates that these behaviours are significant for the development of the self-esteem of the pupils. It is shaped not only under the influence of experienced successes and failures thanks to which the conviction of one's own abilities develops (Niebrzydowski, 1976), but also by the social recognition of a child's competences (Appelt \& Jabłoński, 2004). School grades are an expression of recognition of a child's competences in the Polish education system, hence, the children's desire to be recognised at the highest possible level, which in Poland translates into grades of 5 and 6 . The perception of the support received from persons who are important to them like teachers, among others, is also important for the development of a child's self-esteem (Boyd \& Bee, 2015).

\section{Characteristics of pupils' learning-related needs}

A positive, moderately high self-esteem is an expression of the child developing a sense of competence in the performance of school tasks. The very high proportion 
of statements concerning learning-related needs of pupils, constituting category 2 , a subcategory of which has been presented in Table 6, indicates just how important a sense of competence is for pupils in their fourth and fifth year of school.

\section{Table 6. Subcategories identified within main category no. 2 - Learning-related needs of pupils - 173 statements}

\begin{tabular}{|c|c|}
\hline \multicolumn{2}{|c|}{$\begin{array}{l}\text { Working during lessons under teacher guidance - content of wishes and examples of pupil } \\
\text { statements }[98]^{5}\end{array}$} \\
\hline $\begin{array}{l}\text { Maintaining peace } \\
\text { and quiet necessary to } \\
\text { concentrate on work [40] }\end{array}$ & $\begin{array}{l}\text { For them to ensure peace and quiet during lessons (1P); For boys not to talk } \\
\text { during lessons and for them to be better behaved so that the female teachers } \\
\text { won't have to keep bringing them into line and writing a negative comment } \\
\text { into their journal (1P); It'd like it to be relatively quiet during lessons because } \\
\text { the teachers set us a lot of work and are angry when it's loud (2P); I'd like } \\
\text { there to be silence during lessons (...) because it's noisy and the teacher } \\
\text { doesn't do a good job of making everyone quieten down (3P). }\end{array}$ \\
\hline Slower pace of work [21] & $\begin{array}{l}\text { I'd want teachers (...) not to go so fast with the material to cover }(1 \mathrm{P}) ; \text { What } \\
\text { I'd like to change during lessons is for the teacher to write at their own pace } \\
\text { but wait until the pupils write it down }(2 \mathrm{P}) ;(. .) \text { so that I could have a bit more } \\
\text { time to do the set task, at least } 5-8 \text { minutes }(1 \mathrm{P}) \text {; For the teachers to wait for } \\
\text { everyone when doing set tasks }(2 \mathrm{P}) \text {; For the teachers to dictate tasks more } \\
\text { slowly and explain things more slowly and for one topic to be covered over } \\
2 \text { lessons because then I can understand it quicker (2P); For all the teachers to } \\
\text { speak more slowly (2P); }\end{array}$ \\
\hline $\begin{array}{l}\text { Better explanation of what } \\
\text { the pupil has to learn [17] }\end{array}$ & $\begin{array}{l}\text { I'd like the teachers to explain the topics during lessons more so that I can un- } \\
\text { derstand everything (1P); I want the teachers to better explain what we have } \\
\text { to do at home or during lessons (3P); I'd like the [male] teacher to give simpler } \\
\text { tasks during IT lessons and to explain them several times (3P). }\end{array}$ \\
\hline $\begin{array}{l}\text { More interesting lessons } \\
{[18]}\end{array}$ & $\begin{array}{l}\text { For the teachers to finally use the interactive board (3P); For the lessons not to } \\
\text { be so boring (3P); (...) more group work (3P); }\end{array}$ \\
\hline $\begin{array}{l}\text { Reducing the level of } \\
\text { difficulty of tasks [2] }\end{array}$ & $\begin{array}{l}\text { For the tasks set during maths to be a bit easier (1P); I'd like the (male) } \\
\text { TEACHER not to be as demanding as he is now (2P). }\end{array}$ \\
\hline \multicolumn{2}{|c|}{ Independent work of the pupil- content of wishes and examples of pupil statements [48] } \\
\hline $\begin{array}{l}\text { Setting less/no homework } \\
\text { [41] }\end{array}$ & $\begin{array}{l}\text { Less homework - this stresses us out the most (1P); I'd like there not to be so } \\
\text { much learning and homework (1P); For there not to be any homework (2P); For } \\
\text { us to get less work set because then my school bag will be lighter (2P); For there } \\
\text { to be less work set; there's often too much and we can't relax after lessons (2P). }\end{array}$ \\
\hline $\begin{array}{l}\text { Setting less classwork, } \\
\text { doing fewer tests and } \\
\text { assessments/scrapping } \\
\text { them altogether [7] }\end{array}$ & $\begin{array}{l}\text { For there not to be any tests and assessments (1P); For there not to be any } \\
\text { tests as punishment (3P). }\end{array}$ \\
\hline \multicolumn{2}{|c|}{ Other wishes related to learning - content of wishes and examples of pupil statements [27] } \\
\hline $\begin{array}{l}\text { Changing the teacher of } \\
\text { a given subject [14] }\end{array}$ & $\begin{array}{l}\text { I'd like to change the (given subject) teacher (1P); For there to be a new [fema- } \\
\text { le] (given subject) teacher ( } 2 \mathrm{P}) ; I^{\prime} d \text { like to change my [male] form tutor (2P). }\end{array}$ \\
\hline $\begin{array}{l}\text { Changing the classroom } \\
\text { rules during the lesson [13] }\end{array}$ & $\begin{array}{l}\text { I'd rather sit with my [girl] friend (1P); I'd like to sit with my [girl] friend (1P); } \\
\text { For us to be able to go to the toilet (1P); For us to be able to sit together with- } \\
\text { out having to draw [where we sit] (2P); Sometimes talking during lessons (3P). }\end{array}$ \\
\hline
\end{tabular}

Source: Authors' research.

* The number of respective statements across three measurements has been provided below the names of categories and subcategories. The measurement from which each statement comes has been provided in brackets. 
The pupil statements, on the one hand, point to their motivation to learn and the desire to work during lessons and, on the other, the stress related to failing to understand the topic or not keeping up with other pupils. Perhaps the frustration resulting from this is one of the factors disrupting the peace and quiet during lessons that the pupils miss so much. The situation is exacerbated by the fact that teachers try to bring in discipline during lessons by shouting. The statements of the pupils indicate that they would like to accomplish the school tasks, that they are set on developing their competences but that it is difficult for them to fulfil these goals in the conditions that they have at school. A large number of statements concerning limiting the amount of homework may be indicative of the fact that it is not perceived by the pupils as an interesting challenge, a chance to acquire or consolidate knowledge, and improve their skills and abilities but rather as too great a burden for them to bear.

Also the language used by the children when describing the excessively fast pace of work is noteworthy: for them (the teachers) (...) not to go so fast with the material to cover; (...) the speed of topics covered; (...) help everyone understand the material to cover. These statements signify that the essence of the lessons is "covering material" by the teacher and "its assimilation by the pupils". It is difficult not to notice that this has nothing in common with current knowledge about the conditions of learning and development.

\section{Results of quantitative analyses}

Only the statements of those pupils from whom a complete set of three measurements was obtained was included in the analysis. Figure 1 shows how the percentages of respondents who expressed their approval for the lessons as they are, who suggested changes or failed to respond to the question of their desired changes were changing in subsequent measurements across the given categories of the RI scale.

The Kruskal-Wallis test by ranks (non-parametric ANOVA) was used in each of the three measurements to determine whether the position on the RI scale differentiates the reactions of the respondents to the open question concerning the need for changes during lessons. In the first and second measurement, the differences between the groups turned out to be statistically insignificant: $\mathrm{H}(3, \mathrm{~N}=242)=0.80, \mathrm{p}>0.05 ; \mathrm{H}(3, \mathrm{~N}=242)=0.21 \mathrm{p}>0.05$, respectively. In the third measurement, the test result indicates that the position on the RI scale differentiates the reactions of the respondents to the open questions: $\mathrm{H}(3$, $\mathrm{N}=242)=8.79, \mathrm{p}<0.05$. Based on the percentage distribution, towards the end of the fifth year of learning, pupils with a high risk level of failure in executing 
the developmental task of achieving a sense of competence respond to the open question more frequently and suggest changes in lessons more often than pupils with a lower risk or with no risk in this scope. However, multiple comparisons failed to reveal any statistically significant differences between the groups.

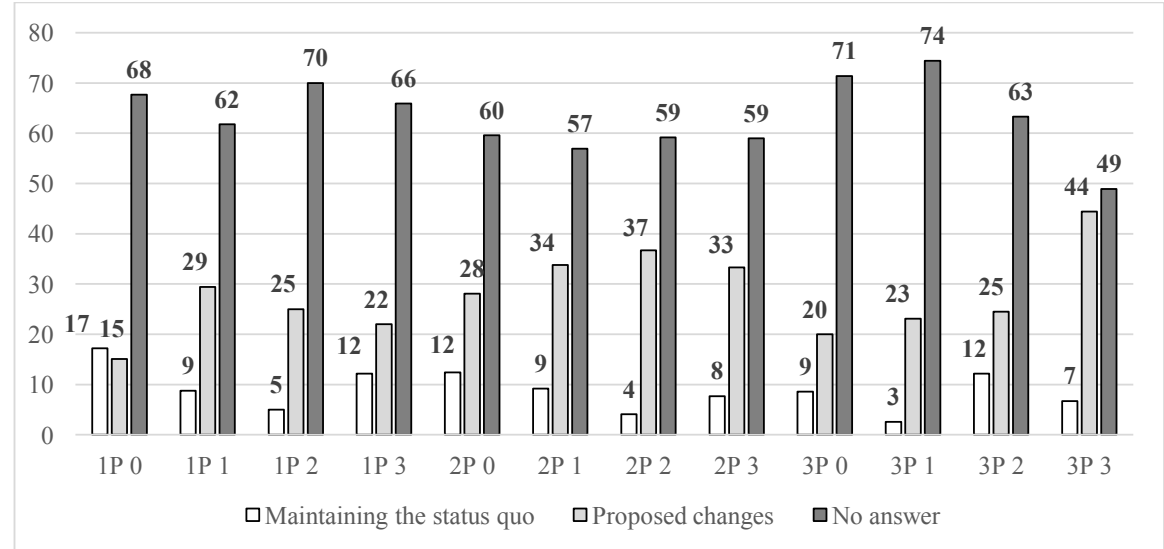

Figure 1. The percentage of respondents accepting the status quo during lessons, proposing changes, and failing to answer the open question, depending on the location on the RI scale across the three measurements.

The symbols use in figure 1: abbreviation $1 \mathrm{P}, 2 \mathrm{P}, 3 \mathrm{P}$-indicates the order of measurements, "0" signifies respondents who are not at risk of being incapable of executing the developmental task; figures from 1 to 3 signify a growing risk of being incapable of executing the task - developing a sense of competence.

Source: Authors' research.

Figure 2 illustrates the percentage distribution of the pupil statements who were allocated to a given category on the RI scale relating to the needs associated with everyday relationships with teachers and the learning-related needs over subsequent measurements.

In the first measurement, only in the group of pupils with an increased risk of failure in the execution of a developmental task was the percentage of responses concerning relationships with teachers higher than the percentage relating to the learning-related needs. In the group of pupils with a high level of risk, statements allocated to both categories appeared with a similar frequency. Pupils not at risk and classified to the average risk category mentioned learningrelated problems more often in their statements. However, an analysis of the data using the Chi-squared test indicates that the observed differences between the groups of pupils distinguished on the RI scale in the first measurement are statistically insignificant (Chi-square $=5.91 ; \mathrm{df}=3 ; \mathrm{p}>0.05)$. 


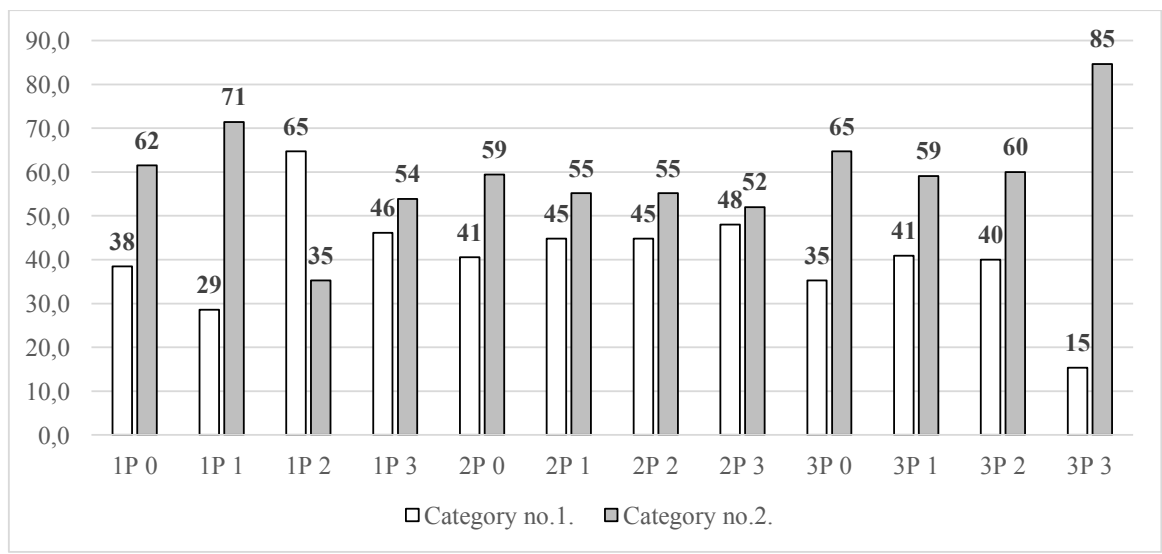

Figure 2. The percentage of pupil responses in category 1 - Pupil needs relating to everyday relationships with teachers, and 2 - Pupil needs related to learning, depending on the position on the RI scale.

The symbols use in figure 2: abbreviation $1 \mathrm{P}, 2 \mathrm{P}, 3 \mathrm{P}$ - indicates the order or measurements, " 0 " next to the symbol of the order of the measurement signifies the respondents allocated to the "no threat of incapacity of execution of the developmental task" category, and figures from 1 to 3 signify a growing degree of risk of failure in executing the task - developing a sense of competence.

Source: Authors' research.

In the second measurement, the differences between the frequency of touching on issues classified as Category 1 and 2 in relevant groups identified on the RI scale are statistically insignificant (Chi-square $=0.95 ; \mathrm{df}=3 ; \mathrm{p}>0.05$ ).

Towards the end of the fifth year of learning, the percentage of responses concerning the teaching process is higher across all groups distinguished on the RI scale than statements describing the treatment of pupils by teachers. The biggest difference occurs in the group of pupils most at risk of failure in the execution of the developmental task (Code 3 on the RI scale). However, the differences between the compared groups are also statistically insignificant in this measurement (Chi-square $=2.76 ; \mathrm{df}=3 ; \mathrm{p}>0.05)$.

\section{Summary}

The responses of pupils to the open question concerning the changes desired by them during lessons allowed for the identification of the school risk factors that hinder the execution of the developmental task of developing a sense of competence. They first and foremost include the manner of teaching, namely, teaching 
everyone the same thing, at the same time, and using the same methods, primarily in the expository form, and a low level of teacher skills in guiding the work of their pupils. Such a teaching style is a cause of stress both for the pupils and for the teachers alike. Some of the pupils react with resistance and certain teachers with shouting, which is an unacceptable form of aggression. This is also the wrong model of coping with frustration for the pupils to follow. An analysis of the wishes of pupils shows that they want to learn during lessons and that homework is a burden for them. Not only do they need a change in the teaching style but also a change in the atmosphere at school, including better emotional contact with teachers and paying more attention to their needs and capabilities. The significance of the climate at school is often raised in the context of the prevention of risk-taking behaviour and the promotion of the mental health of children and adolescents (Wojnarowska-Sołdan, 2007; Junik, 2010; Thapa et al., 2012). The children's utterances indicate that changes are necessary and important for all the pupils, particularly for those who are in the high risk group. For them, learning at school is often an untapped opportunity for developing the potential held by them for their own personal good and for the sake of society as a whole. It seems that change in the understanding and approach to the role of school and teachers is very much called for. School should be a place where pupils not only acquire knowledge and develop their skills and abilities attributed to specific subjects, but also learn work culture alongside other people and, together with them, learn how to influence the reality of school. A teacher should be responsible for the progress that each and every pupil makes under their guidance, particularly the talented ones and those struggling at school with learning difficulties. Without such a radical change in thinking about school and the tasks of teachers, it is difficult to expect the conditions for the psychosocial development of pupils to change for the better.

\section{References}

Appelt, K., \& Jabłoński, S. (2004). Osiągnięcia i zagrożenia dla dziecka w wieku szkolnym. [Achievements and Risks for a School-age Child]. In: A. Brzezińska, \& E. Hornowska (Eds.), Dzieci i młodzież wobec agresji i przemocy [Aggression and Violence as an Experience of Polish Children and Youth], (pp.75-90). Warszawa: Wydawnictwo Naukowe Scholar.

Appelt, K. (2005). Wiek szkolny. Jak rozpoznawać potencjał dziecka [School Age. How to Recognize a Child's Potential?]. In: A. Brzezińska (Ed.), Psychologiczne portrety człowieka [Psychological Portraits of Man], (pp. 259-301). Gdańsk: GWP. 
Ashworth, E., \& Humphrey, N. (2020). More Than the Sum of its Parts: Cumulative Risk Effects on School Functioning in Middle Childhood. British Journal of Educational Psychology, 90, 43-61, doi: 10.1111/bjep.12260 https://doi.org/10.1111/bjep.12260.

Boyd, D., \& Bee, H. (2015). Lifespan Development, 7th ed. Boston: Pearson.

Borsich, S., \& Deptuła, M. (2018). Propozycja narzędzia do pomiaru natężenia poczucia zagrożenia stereotypem wśród dzieci, opracowanego na podstawie koncepcji multizagrożeń Jenessy Shapiro i Stevena Neuberga [A Proposed Tool for Measuring the Intensity of Sensing a Stereotype Threat Among Children, Based on Jenessa Shapiro's and Steven Neuberg's Concept of Multi-Threats]. Studia Edukacyjne, 49, 185-213.

Brzezińska, A.I. (2000). Społeczna psychologia rozwoju [Social Psychology of Development]. Warszawa: Wydawnictwo Naukowe Scholar.

Brzezińska, A.I. (2005a). Jak przebiega rozwój człowieka? [How Human Development Progresses]. In: A.I. Brzezińska (Ed.), Portrety psychologiczne człowieka. Praktyczna psychologia rozwojowa [Psychological Portrais of Man. Practical Developmental Psychology], (pp. 21-39). Gdańsk: GWP.

Brzezińska, A. I. (2005b). Jak myślimy o rozwoju człowieka [How We Think about Human Development]. In: A.I. Brzezińska (Ed.), Psychologiczne portrety człowieka. Praktyczna psychologia rozwojowa [Psychological Portraits of a Person. Practical Developmental Psychology], (pp. 5-19). Gdańsk: GWP.

Brzezińska, A.I., Appelt, K., \& Ziółkowska, B. (2008). Psychologia rozwoju człowieka [Human Developmental Psychology]. In: J. Strelau, \& D. Doliński (Eds.), Psychologia. Podręcznik Akademicki [Psychology. University Textbook], (pp. 95-292). Gdańsk: GWP.

Brzezińska, A.I., Appelt, K., \& Ziółkowska, B. (2016). Psychologia rozwoju człowieka [Human Developmental Psychology]. Sopot: GWP.

Ciżkowicz, B. (2009). Wyuczona bezradność młodzieży [Learned Helplessness of Adolescents]. Bydgoszcz: Wydawnictwo UKW.

Deković, M. (1999). Risk and Protective Factors in the Development of Problem Behavior During Adolescence. Journal of Youth and Adolescence, 28 (6), 667-685, doi: 10.1023/A:1021635516758.

Deptuła, M. (2019). Szanse rozwoju poczucia kompetencji w realizacji zadań szkolnych w klasach IV-VI szkoły podstawowej. Raport z badań empirycznych [Chances for the Development of Competences in the Execution of School Tasks in Classes 4-6 of Primary School. A Report on Empirical Research]. In. P. Kostyło (Ed.), Szkoła równych szans. Namyst teoretyczny i rozwiazania praktyczne [School of Equal Opportunities. Theoretical Mind and Practical Solutions], (pp.118-141). Bydgoszcz, Warszawa: Wydawnictwo Uniwersytetu Kazimierza Wielkiego. 
Deptuła, M., \& Borsich, S. (2017). „Niebieskoocy w naszej szkole” - przezwyciężanie stereotypów drogą do tworzenia uczniom lepszych warunków do rozwoju w klasie szkolnej [The "Blue Eyed" in Our School - Overcoming Stereotypes as the Pathway to Creating Better Conditions for Pupil Development in the School Class]. Studia Edukacyjne, 46, 153-168, doi: 10.14746/se.2017.46.10.

Deptuła, M., Potorska, A., \& Borsich, S. (2018). Wczesna profilaktyka problemów w rozwoju psychospołecznym i ryzykownych zachowań dzieci i młodzieży [Early Prevention of Problems in Psychosocial Development and Risky Behaviour of Children and Adolescents]. Warszawa: Wydawnictwo Naukowe PWN.

Deptuła, M., Borsich, S., \& Borucka, A. (2019). „Niebieskoocy” w naszej szkole.... Raport z realizacji i efektów rocznego planu wspótpracy z nauczycielami klas IV szkoty podstawowej [The "Blue Eyed" in Our School..., A Report on the Execution and Effects of the Annual Plan of Cooperation with Fourth Year Primary School Teachers]. Bydgoszcz, unpublished materials.

Erikson, E.H. (1950). Childhood and Society. New York: W.W. Norton \& Company, Inc.

Forster, M., Amy, G.L., Areba, E., \& McMorris, B.J. (2019). Cumulative Psychosocial Risks, Internal Asse, and Past 30-day Tobacco Use Among Middle and High School Students: The Promise of Internal Assets. Addictive Behaviors, 89, 240-247, doi: 10.1016/j.addbeh.2018.10.014.

Greenberg, M.T. (2006). Promoting Resilience in Children and Youth. Preventive Intervention and Their Interface with Neuroscience. Annals of the New York Academy of Sciences, 1094(1), 139-150, doi: 10.1196/annals.1376.013.

Junik, W. (2010). Pozytywny klimat szkoły szansą dla dzieci z grup ryzyka [A Positive School Climate as an Opportunity for Children from Risk Groups]. In: M. Deptuła (Ed.), Profilaktyka w grupach ryzyka. Część 2. Działania [Prevention in Risk Groups, Part 2. Actions], (pp. 55-72). Warszawa: Wydawnictwo Edukacyjne „Parpamedia”.

Kozłowski, W. (2000). System dydaktyczny i wychowawczy jako źródło zagrożeń psychicznego zdrowia uczniów [Didactic and Educational System as a Source of Threat for the Mental Health of Pupils]. In: Cz. Czabała (Ed.), Zdrowie psychiczne, zagrożenia i promocja [Mental Health: Threats and Promotion], (pp.40-58). Warszawa: Instytut Psychiatrii i Neurologii.

Krejtz, K., \& Krejtz, I. (2005). Metoda analizy treści - teoria i praktyka badawcza [Method of Content Analysis - Theory and Research Practice]. In: K. Stemplewska-Żakowicz, \& K. Krejtz (Ed.), Wywiad psychologiczny. Wywiad jako postępowanie badawcze [Psychological Interview. An Interview as a Research Procedure], (pp.129-148). Warszawa: Pracownia Testów Psychologicznych Polskiego Towarzystwa Psychologicznego.

Kulesza, M. (2007). Klimat szkoły a zachowania przemocowe uczniów w świetle wybranych 
badań empirycznych [School Climate and Violent Behaviour of Pupils in Light of Selected Empirical Studies], Seminare, 24, 261-277.

Kumpfer, K. L., \& Bluth, B. (2004). Parent/Child Transactional Processes Predictive of Resilience or Vulnerability to Substance Abuse Disorders. Substance use \& Misuse, 39, (5), 671-698, doi: 10.1081/JA-120034011.

Ladd, G. W., Herald-Brown, S. L., \& Reiser, M. (2008). Chronic Peer Rejection and Classroom Participation. Does Chronic Classroom Peer Rejection Predict the Development of Children's Classroom Participation During the Grade School Years? Child Development, vol. 79 (4), 1001-1015, doi: 10.1111/j.1467-8624.2008.01172.x.

Masten, A.S., \& Powell, J.L. (2003). A Resilience Framework for Research Policy and Practice. In: S.S. Luthar (Ed.), Resilience and Vulnerability (pp. 1-28). Cambridge University Press, doi: 10.1017/CBO9780511615788.003.

Maslow, A. (1970). Motivation and Personality, 2 ed. Reprinted from the English Edition by Harper \& Row, Publishers 1954.

Mazur, J. (Ed) (2015). Zdrowie i zachowania zdrowotne młodzieży szkolnej w Polsce na tle wybranych uwarunkowań socjodemograficznych. Wyniki badan HBSC 2014 [Health and Health Behaviour of School Adolescents in Poland in Light of Selected Sociodemographic Determinants]. Warszawa: Instytut Matki i Dziecka.

Newcomb, M.D., \& Felix-Ortiz, M. (1992). Multiple Protective and Risk Factors for Drug Use and Abuse: Cross-Sectional and Prospective Findings. Journal of Personality and Social Psychology, 63(2), 280-296, doi: 10.1037/0022-3514.63.2.280.

Niebrzydowski, L. (1976). O poznawaniu i ocenie samego siebie [About Self-Knowledge and Self-Esteem]. Warszawa: Nasza Księgarnia.

Obuchowski, K. (1965). Psychologia dążeń ludzkich [Psychology of Human Strivings]. Warszawa: PWN.

Ostaszewski, K., \& Zimmermann, M.A. (2006). The Effects of Cumulative Risk and Promotive Factors on Urban Adolescent Alcohol and Other Drug Use: A Longitudinal Study of Resilience. American Journal of Community Psychology, 38, 237-249, doi: 10.1007/ s10464-006-9076-x.

Ostaszewski, K. (2014). Zachowania ryzykowne młodzieży w perspektywie mechanizmów resilience [Adolescent Risk Behaviours in the Perspective of Resilience Mechanisms]. Warszawa: Instytut Psychiatrii i Neurologii.

Rogers, C.R. (1961). On Becoming a Person. Boston: Houghton Mifflin Company.

Shapiro, J.R., \& Neuberg, S.L. (2007). From Stereotype Threat to Stereotype Threats: Implications of Multi-Threat Framework of Causes, Moderators, Mediators, Consequ- 
ences, and Interventions. Personality and Social Psychology Review, 11(2), 107-130, doi: $10.1177 / 1088868306294790$.

Seligman, M.E.P., Reivich K., Jaycox L., \& Gillham, J. (1995). The Optimistic Child: Proven Program to Safeguard Children from Depression Build Lifelong Resilience. Australia: Random House.

Smokowski, P.R., Mann, E.A., Reynolds, A.J., \& Fraser, M.W. (2004). Childhood Risk and Protective Factors and Late Adolescent Adjustment in Inner City Minority Youth. Children and Youth Services Review, 26, 63-91, doi: 10.1016/j.childyouth.2003.11.003.

Smykowski, B. (2012). Psychologia kryzysów w kulturowym rozwoju dzieci i młodzieży [Psychology of Crises in the Cultural Development of Children and Adolescents]. Poznań: Wydawnictwo Naukowe UAM.

Steele, C.M., \& Aronson, J. (1995). Stereotype Threat and the Intellectual Test Performance of African-Americans. Journal of Personality and Social Psychology, 69, 797-811, doi: 10.1037/0022-3514.69.5.797.

Stoddard, S.A., Whiteside, L., Zimmermann, M.A., Cunningham, R.M., Chermack, S.T., \& Walton, M.A. (2013). The Relationship Between Cumulative Risk and Promotive Factors and Violent Behavior Among Urban Adolescents. American Journal of Community Psychology, 51, 57-65, doi: 10.1007/s10464-012-9541-7.

Thapa, A, Cohen, J., Higgins-D’Alessandro, A., \& Guffery, S. (2012). School Climate Research Summary: August 2012, National School Climate Center, School Climate Brief, Number 3. Retrieved 9 April 2020 from https://www.schoolclimate.org/storage/app/ media/PDF/sc-brief-v3.pdf.

Witkowski, L. (1989). Rozwój i tożsamość w cyklu życia. Studium koncepcji Erika H. Erikso$n a$ [Development and Identity in the Life Cycle. A Study of Erik H. Erikson's Concept]. Toruń: Uniwersytet Mikołaja Kopernika.

Witkowski, L. (2015). VERSUS. O dwoistości strukturalnej faz rozwoju w ekologii cyklu życia psychodynamicznego modelu Erika H. Eriksona [VERSUS. About the Structural Duality of Development Phases in the Ecology of Life Cycle of Erik H. Erikson's Psychodynamic Model]. Kraków: Impuls, Wyższa Szkoła Biznesu w Dąbrowie Górniczej.

Wojnarowska-Sołdan, M. (2007). Klimat społeczny szkoły - koncepcje i czynniki warunkujące [The Social Climate of School - Concepts and Determinants]. Remedium, 4(170), 22-23.

Żmigrodzki, P. (Ed.) (2007). Wielki Słownik Języka Polskiego PAN [The Polish Academy of Sciences Great Dictionary of Polish]. Kraków: Instytut Języka Polskiego PAN. Retrieved 8 December 2019 from https://wsjp.pl/. 